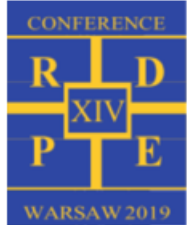

\title{
Speciation of inorganic gaseous species and condensed phases during coconut husk combustion based on thermodynamic equilibrium calculations
}

\author{
Wojciech Jerzak ${ }^{1, *}$, and Monika Kuźnia ${ }^{2}$ \\ ${ }^{1}$ A GH U niversity of Science and Technology, M ickiewicza 30 A v., 30-059 K rakow, wjerzak@ agh.edu.pl, Poland \\ ${ }^{2}$ A GH University of Science and Technology, M ickiewicza 30 A v., 30-059 K rakow, kuznia@agh.edu.pl, Poland
}

\begin{abstract}
Thermodynamic equilibrium calculations to predict coconut husks $(\mathrm{CH})$ combustion products have been carried out in this work. The selected type of biomass belongs to problematic fuels due to the fibrous structure preventing its grinding, and high chlorine content. The calculations results showed, that the combustion temperature for the tested range of $600-1000^{\circ} \mathrm{C}$ clearly affects the concentrations of chlorine species in the flue gas. When the temperature was below $820^{\circ} \mathrm{C}$, the highest concentration had $\mathrm{HCl}(\mathrm{g})$, and above $820^{\circ} \mathrm{C} \mathrm{KCl}(\mathrm{g})$. The chlorine was also present in ash, as $\mathrm{KCl}-\mathrm{NaCl}-\mathrm{RbCl}$ solid solution, when the combustion temperature $\mathrm{T} \leq 700^{\circ} \mathrm{C}$, and $\mathrm{KCl}-\mathrm{NaCl}-\mathrm{K}_{2} \mathrm{SO}_{4}-\mathrm{N} \mathrm{a}_{2} \mathrm{SO}_{4}$ liquid solution, when $600 \leq \mathrm{T} \leq 960{ }^{\circ} \mathrm{C}$. High content of chlorine in ash from $\mathrm{CH}$ combustion at $\mathrm{T}=650^{\circ} \mathrm{C}$ has been confirmed experimentally. Speciations of inorganic gaseous species and condensed phases we investigated also during flue gas cooling from 1000 to $400^{\circ} \mathrm{C}$. M ajor condensed phase composition were dominated by alkali metal salts in both solid and liquid phase states. Finally, we presented sixteen eutectic points for different binary systems calculated in the FactSage software.
\end{abstract}

\section{Introduction}

The long-term European Union policy related to the reduction of $\mathrm{CO}_{2}$ emissions from the fossil fuels combustion is an incentive for the development of technologies that use waste biomass for energy production. Biomass is considered as a renewable carbonneutral fuel. However, there are many problems associated with the use of lignocellulosic biomass as a fuel, e.g.: high moisture content, low heating value, high chlorine, sulfur and alkali metal elements contents responsible for fouling, corrosion and slagging, and its fibrous structure makes biomass difficult to grind. The behaviour of the inorganic part of biomass during the combustion process [1-3], and cooling of products gas [47], can be determined by thermodynamic equilibrium prediction. The trends of the main solid and liquid phases formation as a function of combustion temperature under equilibrium conditions were investigated by $\mathrm{K}$ aknics et al. [1]. They confirmed, among others that the low temperature of biomass combustion (below $800{ }^{\circ} \mathrm{C}$ ) favors the formation of the alkali salts: $\mathrm{KCl}(\mathrm{s}), \mathrm{NaCl}(\mathrm{s})$, $\mathrm{K}_{2} \mathrm{SO}_{4}(\mathrm{~s}), \mathrm{Na}_{2} \mathrm{SO}_{4}(\mathrm{~s})$ in ash. Part of the potassium reacts with the biomass-ash in the combustion chamber forming silicates: $\mathrm{K}_{2} \mathrm{Si}_{4} \mathrm{O}_{6}(\mathrm{~s}), \mathrm{Ca}_{3} \mathrm{~K}_{2} \mathrm{Si}_{6} \mathrm{O}_{16}(\mathrm{~s})$ or $\mathrm{K}_{2} \mathrm{Si}_{3} \mathrm{M} \mathrm{gO}_{8}(\mathrm{~s})$. In turn, Wei et al. [2] indicated: $\mathrm{KCl}(\mathrm{g}), \mathrm{KOH}(\mathrm{g})$ and $\mathrm{K}_{2} \mathrm{SO}_{4}(\mathrm{~g})$ as the main constituents of the flue gas containing alkali. Furthermore, the air excess coefficient has a limited effect on the release of chlorine, potassium and sodium, whereas the increase in pressure can enhances the release of $\mathrm{HCl}(\mathrm{g})$ and reduces the formation of $\mathrm{KCl}(\mathrm{g}), \mathrm{NaCl}(\mathrm{g}), \mathrm{KOH}(\mathrm{g})$ and $\mathrm{NaOH}(\mathrm{g})$ at high temperatures. The release of inorganic gaseous species is controlled by the trace elements that compete for chlorine and sulfur [3]. Increased concentration of $\mathrm{HCl}(\mathrm{g})$ in the combustion chamber reduces the retention of $\mathrm{Cd}, \mathrm{Cu}, \mathrm{M} \mathrm{n}$, $\mathrm{Zn}, \mathrm{Cr}$ and $\mathrm{Ni}$ in the biomass-ash. During the cooling of the flue gas, the condensation of alkali salts vapors occurs. The vapors condensed, and can easily form the eutectics e.g. $\mathrm{NaCl}-\mathrm{KCl}, \mathrm{NaCl}-\mathrm{Na}_{2} \mathrm{SO}_{4}$, with lower melting point than the pure salts [4, 5]. A s reported by Froment et al. [6] condensation of $\mathrm{K}$ and $\mathrm{Cl}$ is favoured, when the total pressure is increased. The condensed phase formed when the gas is cooled contains not only salts, but also metal oxides and hydroxides such as: $\mathrm{FeO}(\mathrm{s}), \mathrm{Fe}_{2} \mathrm{O}_{3}(\mathrm{~s})$, $\mathrm{Na}_{2} \mathrm{O}(\mathrm{s}), \mathrm{NaOH}(\mathrm{s}, \mathrm{I})$ an $\mathrm{KOH}(\mathrm{s}, \mathrm{I})[7]$.

\section{Materials and Methods}

\subsection{Coconut husk}

This work focuses on the fate of inorganics during coconut husk $(\mathrm{CH})$ combustion. $\mathrm{CH}$ is an agricultural waste from coconut processing. The world leaders in coconut production are: Indonesia, Philippines, India, and $\mathrm{Brazil}$ [8]. $\mathrm{CH}$ is a high-calorie energy source containing a lot of lignin and cellulose. It has a large potential for use in power plants, due to availability and low price. At present, $\mathrm{CH}$ is used as domestic fuel, a fiber source for ropes, for biochar production, and as potential silica source $[9,10]$. Table 1 presents proximate, ultimate and trace elements analysis of $\mathrm{CH}$. All analyses were performed with three replicates in the Central Laboratory of Energopomiar in Gliwice, and Table 1 shows the mean 
values. $\mathrm{CH}$ were tested in accordance with PN-EN ISO standards: 18134-2:2017-03 - M oisture, 18122:2016-01 — A sh, 18123:2016-01 — V olatile matter, 16948:2015$07-\mathrm{C}, \mathrm{H}$, and $\mathrm{N}, 16994: 2016-10-\mathrm{S}$, and $\mathrm{Cl}$, 18125:2017-07 - Lower Heating Value (LHV), 16968:2015:07 — Trace elements. Whereas $\mathrm{Hg}$ determination was carried out in accordance with EPA Method 7473: 2007. $\mathrm{CH}$ contain as much as $1.9 \%$ chlorine. The chlorine accumulated in the husk comes from the fertilization system including sodium chloride or potassium chloride [8]. According to $\mathrm{CH}$ analysis, the molar ratio $2 \mathrm{~S} /(\mathrm{K}+\mathrm{Na})$ is 0.08 . V alues bel ow 5 indicate a high propensity to create a deposit consisting of alkali chlorides [11]. In this case, the sulphation process reducing the tackiness of the deposit is very limited. There are also TEs present in $\mathrm{CH}$ among others: $\mathrm{Rb}, \mathrm{Sn}, \mathrm{Pb}, \mathrm{B}$, with concentrations above $10 \mathrm{mg} / \mathrm{kg}$ of dry fuel.

Table 1. Coconut husk analysis.

\begin{tabular}{|c|c|}
\hline Proximate analysis (as received) & $\%$ \\
\hline Moisture & 8.5 \\
\hline Ash & 5.39 \\
\hline Volatile matter & 61.5 \\
\hline Calorific Value (dry) & $\mathbf{M J} / \mathbf{k g}$ \\
\hline HHV & 19.31 \\
\hline LHV & 18.22 \\
\hline Ultimate analysis (dry) & $\%$ \\
\hline $\mathrm{C}$ & 49.59 \\
\hline $\mathrm{H}$ & 5.3 \\
\hline $\mathrm{N}$ & 0.38 \\
\hline S & 0.06 \\
\hline $\mathrm{Cl}$ & 1.9 \\
\hline $\mathrm{O}^{\text {diff }}$ & 36.87 \\
\hline Trace elements (dry) & $\mathrm{mg} / \mathrm{kg}$ \\
\hline $\mathrm{Zn}$ & 7.46 \\
\hline $\mathrm{Cu}$ & 4.24 \\
\hline $\mathrm{Pb}$ & 17.1 \\
\hline $\mathrm{Ni}$ & 1.04 \\
\hline $\mathrm{Cr}$ & 1.14 \\
\hline $\mathrm{Cd}$ & $<0.06$ \\
\hline Co & $<0.1$ \\
\hline As & $<1$ \\
\hline V & $<0.5$ \\
\hline $\mathrm{Sb}$ & $<1.5$ \\
\hline $\mathrm{Ba}$ & 9.24 \\
\hline $\mathrm{Sr}$ & 8.19 \\
\hline Mo & $<3.2$ \\
\hline Sn & 17.8 \\
\hline $\mathrm{Rb}$ & 47.1 \\
\hline $\mathrm{Li}$ & $<0.15$ \\
\hline B & 11.8 \\
\hline $\mathrm{Hg}$ & 0.008 \\
\hline
\end{tabular}

TEs may react with chlorine and sulfur during combustion, so their identification in biomass plays an important role. A s many as eighteen TEs listed in Table 1 were identified in $\mathrm{CH}$, and $\mathrm{Cd}, \mathrm{Co}, \mathrm{As}, \mathrm{V}, \mathrm{Sb}, \mathrm{Mo}$, and $\mathrm{Li}$ were below the measurement range of the apparatus.

\subsection{Ash}

A sh from $\mathrm{CH}$ was obtained by biomass combustion at $650^{\circ} \mathrm{C}$ in an electric heated tube furnace. Chemical composition of ash included in Table 2 presents the average values from the three samples, and has been determined with the method of inductively coupled plasma optical emission spectrometry (ICP-OES) with the use of a plasma spectrometer Thermo iCA P 6500 D uo ICP. Chlorine and carbonates were determined according to the following standards: PN-EN 196-2: 2013-11, and PN-EN 15936: 2013-02. As can be seen from Table 2, silicon and potassium oxides predominate in the ash composition. Chlorine contained in ash accounts for 10.8 $\%$ of mass ash, which is in line with the value obtained by other researchers [12].

Table 2. Ash composition from $\mathrm{CH}$ at $650^{\circ} \mathrm{C}$

\begin{tabular}{|c|c|}
\hline Component & \% \\
\hline $\mathrm{SiO}_{2}$ & 31.6 \\
\hline $\mathrm{Fe}_{2} \mathrm{O}_{3}$ & 11.9 \\
\hline $\mathrm{Al}_{2} \mathrm{O}_{3}$ & 3.0 \\
\hline $\mathrm{Mn}_{3} \mathrm{O}_{4}$ & 0.10 \\
\hline $\mathrm{TiO}_{2}$ & 0.30 \\
\hline $\mathrm{CaO}_{2}$ & 2.33 \\
\hline $\mathrm{MgO}$ & 2.19 \\
\hline $\mathrm{P}_{2} \mathrm{O}_{5}$ & 1.60 \\
\hline $\mathrm{SO}_{3}$ & 1.12 \\
\hline $\mathrm{Na}_{2} \mathrm{O}$ & 4.82 \\
\hline $\mathrm{K}_{2} \mathrm{O}$ & 27.5 \\
\hline $\mathrm{CO}_{2}$ & 1.5 \\
\hline $\mathrm{Cl}$ & 10.8 \\
\hline
\end{tabular}

\subsection{Software and thermochemical database}

Thermodynamic equilibrium calculations were performed in the Equilib module of the FactSage 6.3 commercial software. Thermodynamic equilibrium predictions are based on the minimizing of the total Gibbs free energy:

$$
\begin{gathered}
G=\sum_{\begin{array}{c}
\text { ideal } \\
\text { gas }
\end{array}} n_{i}\left(g_{i}^{\circ}+R T \ln p_{i}\right)+\sum_{\begin{array}{c}
\text { pure } \\
\text { condensed } \\
\text { phases }
\end{array}} n_{i} g_{i}^{\circ}+ \\
\sum_{\text {solution } 1} n_{i}\left(g_{i}^{\circ}+R T \ln X_{i}+R T \ln \gamma_{i}\right)+ \\
\sum_{\text {solution 2 }} n_{i}\left(g_{i}^{\circ}+R T \ln X_{i}+R T \ln \gamma_{i}\right)+\cdots
\end{gathered}
$$


where:

$n_{i}, g_{i}^{\circ}, X_{i}, \gamma_{i}$ - successively moles, standard molar Gibbs energy, mole fraction, and activity coefficient of component "i",

$$
\begin{array}{ll}
p_{i} & - \text { partial pressure of the gas component " } \mathrm{i} \text { ", } \\
R & - \text { universal gas constant, } \\
T & - \text { temperature. }
\end{array}
$$

The system achieves thermodynamic equilibrium state, when:

$$
\begin{gathered}
G=\min ., \quad \text { or } \\
d G=0
\end{gathered}
$$

The equilibrium criterion in equation (2) is mainly valid in multi-phase multicomponent systems.

In Equilib module, the following thermochemical databases were selected for pure components and solutions: FactPS, FToxide, ASalt-liq, FTpulp, and FT salt. In addition, the Phase Diagram module was used to determine eutectic points in binary systems.

\subsection{Calculation procedure}

The calculation procedure covers two cases. The first is the combustion of $1 \mathrm{~kg}$ dry biomass, in the temperature range from 600 to $1000{ }^{\circ} \mathrm{C}$ with a $20^{\circ} \mathrm{C}$ steps, and $\lambda=1.2$. In the second case, the flue gas are cooled from 1000 to $400^{\circ} \mathrm{C}$, also with a $20^{\circ} \mathrm{C}$ step.

\section{Result and discussion}

\subsection{Speciation of minor inorganic gaseous species calculated at different combustion temperature}

The main flue gas components from $\mathrm{CH}$ combustion in the studied temperature range are: $\mathrm{N}_{2}>\mathrm{CO}_{2}>\mathrm{H}_{2} \mathrm{O}>\mathrm{O}_{2}>\mathrm{Ar}$. In addition, minor inorganic gaseous species are also present in the flue gas, the concentration of which varies with the combustion temperature. Figure 1 shows flue gas components present in minor quantities, i.e. $\geq 1 \mathrm{mg} / \mathrm{m}^{3}$ wet flue gas. The fuelbond chlorine during $\mathrm{CH}$ combustion reacts with potassium, hydrogen, sodium, and rubidium. When the combustion temperature is in the range of $600-780{ }^{\circ} \mathrm{C}$, the flue gas are dominated by $\mathrm{HCl}$. Increased concentration of $\mathrm{HCl}$ in the combustion chamber reduces the retention of $\mathrm{Cd}, \mathrm{Cu}, \mathrm{M} \mathrm{n}, \mathrm{Zn}, \mathrm{Cr}$ and $\mathrm{Ni}$ in the biomass-ash [3]. $\mathrm{HCl}$ have an inhibiting effect on biomass burning and $\mathrm{CO} \rightarrow$ $\mathrm{CO}_{2}$ oxidation [13]. $\mathrm{HCl}$ can easily be removed from the flue gas by a scrubbing process [13], or using an alkalinecarbonate sorbent [14], therefore, it belongs to the desired products containing chlorine. The following chlorides are also present in the flue gas: $\mathrm{KCl}, \mathrm{NaCl}, \mathrm{RbCl}$, as dimers $\mathrm{K}_{2} \mathrm{Cl}_{2}$ and $\mathrm{Na}_{2} \mathrm{Cl}_{2}$. An increase in the combustion temperature above $780{ }^{\circ} \mathrm{C}$, clearly promotes release of $\mathrm{KCl}, \mathrm{K}_{2} \mathrm{Cl}_{2}, \mathrm{NaCl}$, and reduction of $\mathrm{HCl}$. As a result, the $\mathrm{KCl}$ concentration is fivefold as high as $\mathrm{HCl}$ at $1000{ }^{\circ} \mathrm{C}$. Due to its high propensity to form aerosols in the cooling process, $\mathrm{KCl}$ is an undesirable constituent of flue gas, that contributes to deposition and corrosion. A part from N O,
$\mathrm{Na}_{2} \mathrm{Cl}_{2}$ and $\mathrm{SO}_{2}$ in flue gas two trace elements $(\mathrm{Rb}$, and B) can also be observed as $\mathrm{RbCl}, \mathrm{H}_{3} \mathrm{BO}_{3}$ and $\mathrm{KBO}_{2}$. The positive correlation of the increase in the volume of flue gases with temperature (resulting from the decrease in density) is the reason for the reduction of $\mathrm{RbCl}$ concentration in Fig. 1.

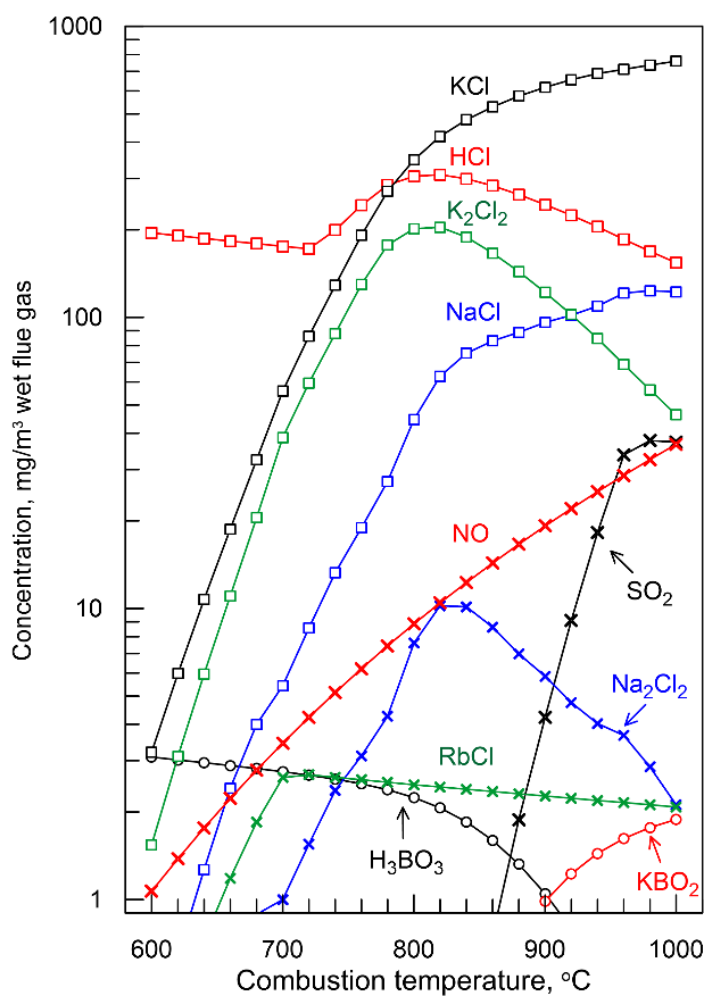

Fig. 1. Speciation of minor inorganic gaseous species $(\geq 1$ $\mathrm{mg} / \mathrm{m}^{3}$ ) during $\mathrm{CH}$ combustion in air.

\subsection{Speciation of the condensed phase during $\mathrm{CH}$ combustion}

The condensed phases shown in Fig. 2 are divided into three groups: a) alkali metal salts (solid and liquid), b) other solid salts, and c) solid oxides. Caring for the readability of Fig. 2, ash components with concentrations below $0.1 \mathrm{~g} / \mathrm{kg}$ ash, i.e. $\mathrm{BaCrO}_{4}$ and $\mathrm{NiTiO}_{3}$, were not included. Although the low combustion temperature $\left(<700{ }^{\circ} \mathrm{C}\right)$ inhibits potassium and sodium evaporation, however, these alkali are susceptible to forming the liquid solution $\mathrm{KCl}-\mathrm{NaCl}-\mathrm{K}_{2} \mathrm{SO}_{4}-\mathrm{Na}_{2} \mathrm{SO}_{4}$ already at a temperature of $600{ }^{\circ} \mathrm{C}$. As known, chlorides and sulphates present in the ash, they interact with each other, and the melting temperature of the mixture is lower than the melting temperature of the individual salts [15]. The maximum total mass of the liquid salt solution was achieved at $720{ }^{\circ} \mathrm{C}$, and the disappearance of the liquid phase at $980{ }^{\circ} \mathrm{C}$. Potassium, sodium and rubidium chlorides in their solid state are formed only in the temperature range of $600-700{ }^{\circ} \mathrm{C}$. A ccording to Fig. 2b), the masses of individual solid ash components are conditioned by the combustion temperature. Only three solid salt compounds are present in the ash in the entire temperature range tested, ie. $\mathrm{KAI}_{2} \mathrm{SiO}_{6}, \mathrm{Na}_{2} \mathrm{Ca}_{3} \mathrm{Si}_{6} \mathrm{O}_{16}$, and $\mathrm{SrTiO}_{3}$. Other salts are contained in the ash only in specific temperature ranges, with noticeable 


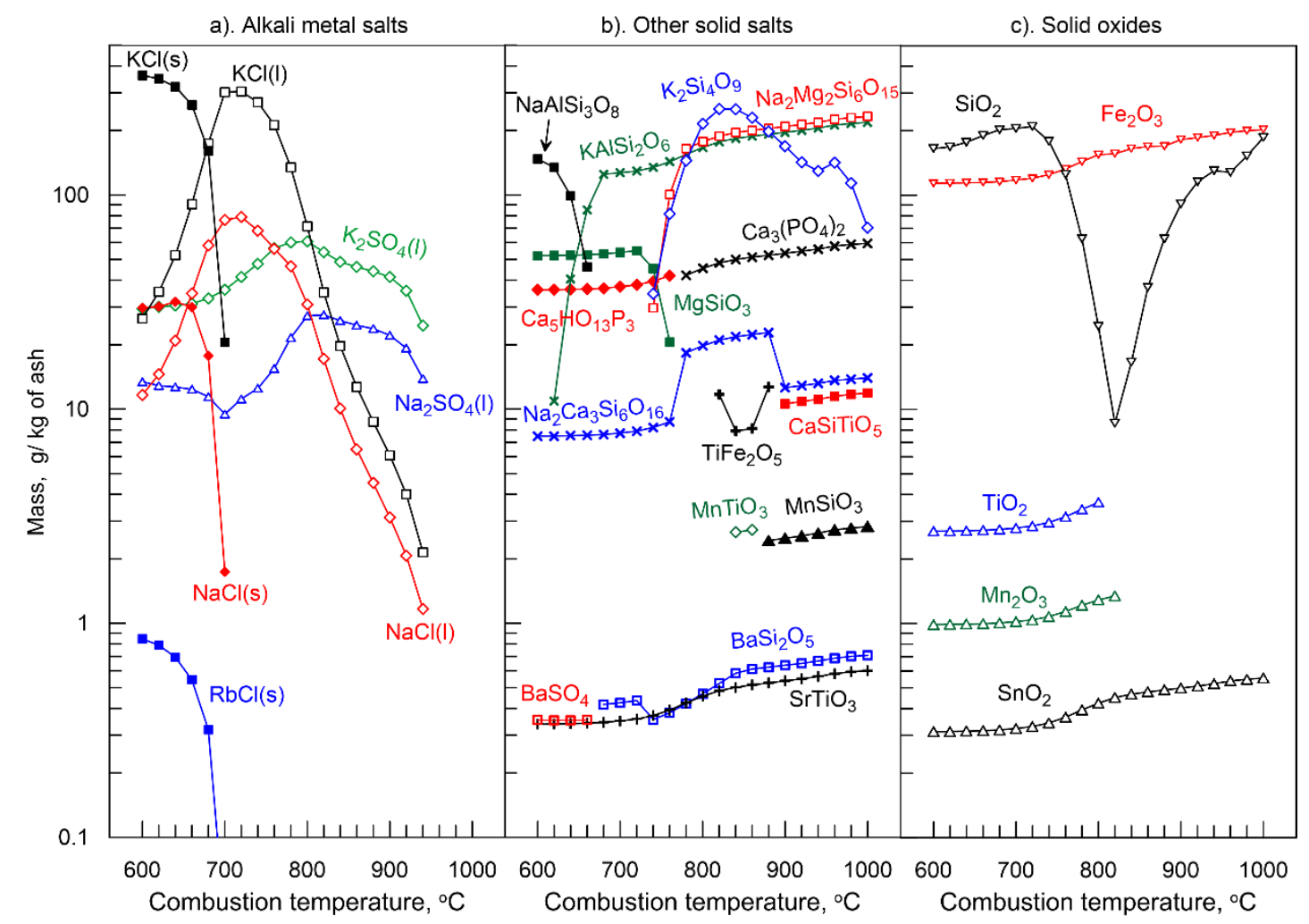

Fig. 2. Speciation of the condensed phase during $\mathrm{CH}$ combustion: a). alkali metal salts, b). other solid salts, and c). solid oxides.

transformations, e.g. $\mathrm{Ca}_{5} \mathrm{HO}_{13} \mathrm{P}_{3} \quad\left(\mathrm{~T} \leq 860{ }^{\circ} \mathrm{C}\right) \rightarrow$ $\mathrm{Ca}_{3}\left(\mathrm{PO}_{4}\right)_{2}\left(\mathrm{~T} \geq 880^{\circ} \mathrm{C}\right)$. In addition to salt, solid oxides are also thermodynamic predicted in ash: $\mathrm{SiO}_{2}, \mathrm{Fe}_{2} \mathrm{O}_{3}$, $\mathrm{TiO}_{2}, \mathrm{Mn}_{2} \mathrm{O}_{3}$, and $\mathrm{SnO}_{2}$. The minimum $\mathrm{SiO}_{2}$ concentration in Fig. 2c) occurs at the same temperature $\left(820{ }^{\circ} \mathrm{C}\right)$ as the maximum $\mathrm{K}_{2} \mathrm{Si}_{4} \mathrm{O}_{9}$ in Fig. 2b). The formation of potassium silicates depends on the molar ratios between the reactants and the gas atmosphere. When $\mathrm{SiO}_{2}: \mathrm{K}_{2} \mathrm{CO}_{3}$ or $\mathrm{SiO}_{2}: \mathrm{KCl}$ molar ratios is 4 or more, the formation of $\mathrm{K}_{2} \mathrm{Si}_{4} \mathrm{O}_{9}$ occurs according to the reactions $[16,17]$ :

$$
\begin{gathered}
4 \mathrm{SiO}_{2(s)}+\mathrm{K}_{2} \mathrm{CO}_{3(s)} \rightleftharpoons \mathrm{K}_{2} \mathrm{Si}_{4} \mathrm{O}_{9(g)}+\mathrm{CO}_{2(g)} \\
4 \mathrm{SiO}_{2(s)}+\mathrm{KCl}_{(l)}+\mathrm{H}_{2} \mathrm{O}_{(g)} \rightleftharpoons \\
\mathrm{K}_{2} \mathrm{Si}_{4} \mathrm{O}_{9(g)}+2 \mathrm{HCl}_{(g)}
\end{gathered}
$$

\subsection{Speciation of the condensed phase during the flue gas cooling}

Condensable components during the flue gas cooling, was shown in Figs. 3a-b). Major condensed phase composition is dominated by alkali metal salts in both solid and liquid phase states. The liquid $\mathrm{KCl}-\mathrm{NaCl}-$ $\mathrm{K}_{2} \mathrm{SO}_{4}-\mathrm{Na}_{2} \mathrm{SO}_{4}$ salt solution begins to form after the flue gas has been cooled to $960{ }^{\circ} \mathrm{C}$. The flue gas cooling promotes an increase in the mass of liquid salt solution up to a temperature of $700{ }^{\circ} \mathrm{C}$. The equilibrium between alkali $(\mathrm{Me}=\mathrm{K}$, or $\mathrm{Na})$ chlorides and sulphates is determined on the basis of a series of reactions in which reactions (6) and (7) plays a leading role [18]:

$$
\begin{gathered}
2 \mathrm{MeCl}_{(g)}+\mathrm{H}_{2} \mathrm{O}_{(g)}+\mathrm{SO}_{2(g)}+\frac{1}{2} \mathrm{O}_{2(g)} \rightleftharpoons \\
\mathrm{Me}_{2} \mathrm{SO}_{4(l)}+2 \mathrm{HCl}_{(g)}
\end{gathered}
$$

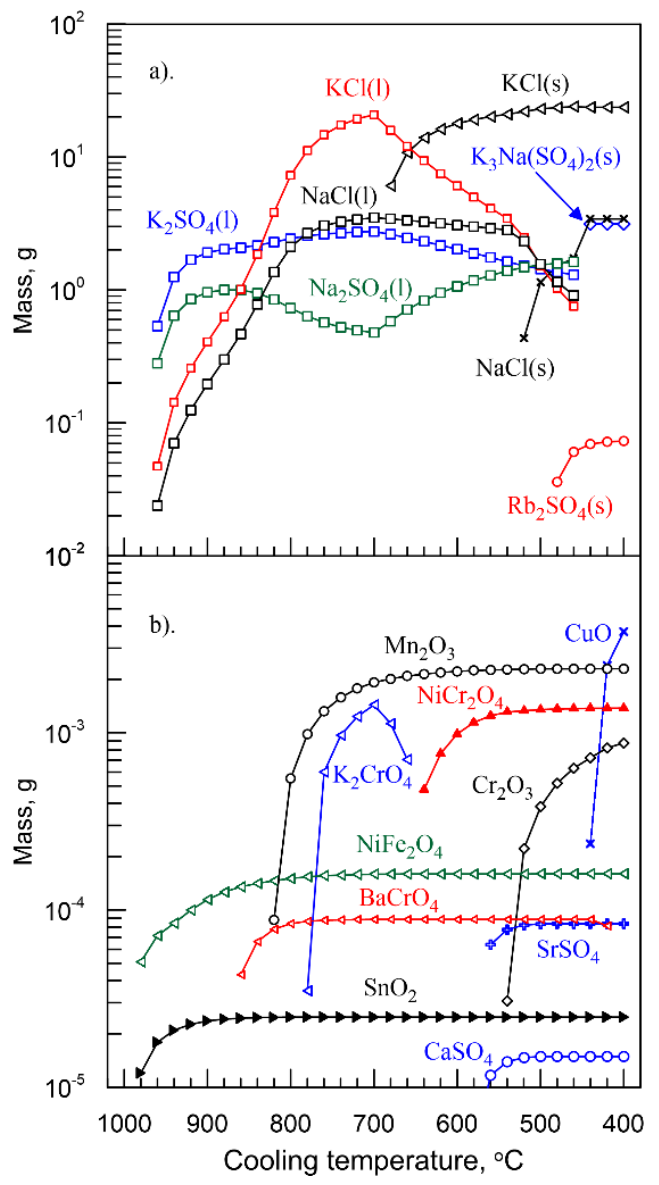

Fig. 3. Speciation of the condensed phase during the flue gas cooling: a). major condensed species, b). minor solid species. 


$$
\begin{gathered}
2 \mathrm{MeCl}_{(g)}+\mathrm{SO}_{2(g)}+\mathrm{O}_{2(g)} \rightleftharpoons \\
\mathrm{Me}_{2} \mathrm{SO}_{4(l)}+\mathrm{Cl}_{2(g)}
\end{gathered}
$$

As a result, the cooled flue gas contains less $\mathrm{NaCl}(\mathrm{g})$ and $\mathrm{KCl}(\mathrm{g})$, while more $\mathrm{HCl}(\mathrm{g})$ and $\mathrm{Cl}_{2(\mathrm{~g})}$. Further $\mathrm{HCl}(\mathrm{g})$ reacts with oxygen, according to the Deacon reaction:

$$
2 \mathrm{HCl}_{(g)}+\frac{1}{2} \mathrm{O}_{2(g)} \rightleftharpoons \mathrm{Cl}_{2(g)}+\mathrm{H}_{2} \mathrm{O}_{(g)}
$$

and the content of $\mathrm{Cl}_{2}$ increases in the flue gas.

According to Fig. 3b), minor solid species $(<0.01 \mathrm{~g})$ are also forming in the flue gas cooling process. The cooler the flue gas, the more species it condenses (for example, at $980^{\circ} \mathrm{C}$ there are only two species, while at $420{ }^{\circ} \mathrm{C}$ as many as nine. Interestingly, based on thermodynamic prediction, condensed species form both salts and metal oxides. In the entire studied temperature range, only $\mathrm{NiFe}_{2} \mathrm{O}_{4}$ and $\mathrm{SnO}_{2}$ have condensed. The remaining condensed components were only present in specific temperature ranges.

\subsection{Eutectic points}

In order to supplement the analysis of the occurrence of liquid species in the process of $\mathrm{CH}$ combustion and exhaust gas cooling, additional calculations were performed using the Phase Diagram module, determining eutectic points in binary systems. All calculations were carried out for a pressure of $1 \mathrm{~atm}$, and the shares of components in binary systems were given in mass $\%$. Calculations were made for sixteen binary systems, and the system with the lowest liquid temperature is presented in Fig. 4. The eutectic point for the $\mathrm{FeCl}_{2}-\mathrm{KCl}$ phase diagram is determined by the composition of $48 \%$ mass $\mathrm{KCl}$ and $52 \%$ mass. $\mathrm{FeCl}_{2}$ at $351{ }^{\circ} \mathrm{C}$.

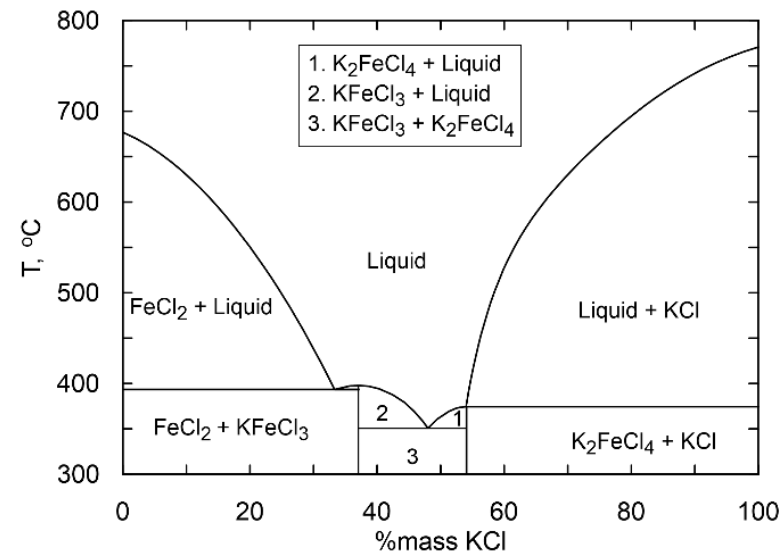

Fig. 4. Binary phase diagram of $\mathrm{FeCl}_{2}-\mathrm{KCl}$ - calculated in the FactSage software.

The calculation results for selected binary systems are summarized in Table 3 . The values are ordered according to lowest melting temperature, corresponding to the eutectic point. At this point, it should be emphasized that only binary phase systems are listed in Table 3, for which thermodynamic databases have already been developed. The authors of this article are aware of the need for further research in order to create databases for other systems, eg $\mathrm{KCl}-\mathrm{Na}_{2} \mathrm{SO}_{4}\left(515^{\circ} \mathrm{C}, 57 \%\right.$ mass $\left.\mathrm{KCl}\right)$ [19].
Table 3. Eutectic points for different binary systems calculated in the FactSage software.

\begin{tabular}{|c|c|c|}
\hline System & $\begin{array}{c}\text { Eutectic } \\
\text { temperature, } \\
{ }^{\circ} \mathrm{C}\end{array}$ & $\begin{array}{c}\text { Composition at } \\
\text { eutectic point, } \\
\text { mass } \%\end{array}$ \\
\hline $\mathrm{KCl}-\mathrm{FeCl}_{2}$ & 351 & 48 \\
\hline $\mathrm{K}_{2} \mathrm{CO}_{3}-\mathrm{KOH}$ & 365 & 20 \\
\hline $\mathrm{K}_{2} \mathrm{SO}_{4}-\mathrm{KOH}$ & 385 & 17 \\
\hline $\mathrm{KCl}-\mathrm{KOH}$ & 392 & $1 \rightarrow 20$ \\
\hline $\mathrm{KCl}-\mathrm{PbCl}_{2}$ & 408 & 20 \\
\hline $\mathrm{K}_{2} \mathrm{SO}-\mathrm{Li}_{2} \mathrm{SO}_{4}$ & 549 & 26 \\
\hline $\mathrm{NaCl}_{-}-\mathrm{RbCl}$ & 550 & 27.6 \\
\hline $\mathrm{K}_{2} \mathrm{O}-\mathrm{SiO}_{2}$ & 584 & 61 \\
\hline $\mathrm{KCl}-\mathrm{CaCl}_{2}$ & 601 & 67 \\
\hline $\mathrm{K}_{2} \mathrm{O}-\mathrm{Na}_{2} \mathrm{O}$ & 602 & 84 \\
\hline $\mathrm{KCl}-\mathrm{K}_{2} \mathrm{CO}_{3}$ & 617 & 47 \\
\hline $\mathrm{NaCl}_{-}-\mathrm{Na}_{2} \mathrm{SO}_{4}$ & 625 & 32 \\
\hline $\mathrm{KCl}-\mathrm{NaCl}_{2}$ & 657 & 58.6 \\
\hline $\mathrm{KCl}_{-} \mathrm{K}_{2} \mathrm{SO}_{4}$ & 691 & 56 \\
\hline $\mathrm{Na}_{2} \mathrm{O}-\mathrm{Na}_{2} \mathrm{SO}_{4}$ & 781 & 11 \\
\hline $\mathrm{K}_{2} \mathrm{SO}_{4}-\mathrm{Na}_{2} \mathrm{SO}_{4}$ & 824 & 30 \\
\hline
\end{tabular}

\section{Conclusions}

In this work, thermodynamic equilibrium calculations were performed in the FactSage 6.3 software, with the customized thermodynamic database for predicting the elemental composition of gaseous species and condensed phases under different temperature. Based on thermodynamic prediction, it has been shown that the dominant inorganic gaseous species of flue gas are: $\mathrm{KCl}(\mathrm{g}), \mathrm{HCl}(\mathrm{g}), \mathrm{K}_{2} \mathrm{Cl}_{2}$ (g), and $\mathrm{NaCl}(\mathrm{g})$. Interpreting the calculation results of the combustion process, three groups were distinguished among condensed phases: a) alkali metal salts (solid and liquid), b) other solid salts, and c) solid oxides. $\mathrm{KCl}(\mathrm{s}), \mathrm{NaCl}(\mathrm{s})$ and $\mathrm{RbCl}(\mathrm{s})$ are formed only in the temperature range of $600-700{ }^{\circ} \mathrm{C}$. It has been shown, that solid and liquid ash components are dependent by the combustion temperature. The consequence of flue gas cooling was the formation of a condensed phase. The phase composition was dominated by alkali metal salts in both solid and liquid states. The more strongly the exhaust gases were cooled, the more species of condensed phases therein were revealed. Finally, we analyzed sixteen binary systems for which eutectic points were determined.

This work was financially supported by the AGH University of Science and Technology (D.S. no. 16.16.110.663).

\section{References}

1. Kaknics J., Defoort F., Poirier J., Energy Fuels, Vol. 29, pp. 6433-6442, (2015). 
2. Wei X., Schnell U., Hein K.R.G., Fuel, Vol. 84, pp. 841-848, (2005).

3. Miller B., Dugwell D.R., Kandiyoti R., Energy Fuels, Vol. 17, pp. 1382-1391, (2003).

4. Wang Y., Tan H., Wang X., Cao R., Wei B., Fuel, Vol. 187, pp. 33-42, (2017).

5. Lindberg D., Niemi J., Engblom M., Yrjas P., Laurén T., Hupa M., Fuel Processing Technology, Vol. 141, pp. 285-298, (2016).

6. Froment K., Defoort F., Bertrand C., Seiler J.M., Berjonneau J., Poirier J., Fuel, Vol. 107, pp. 269281, (2013).

7. Wan W., Engvall K., Yang W., Fredriksson Möller B., Energy, Vol. 153, pp. 35-44, (2018).

8. Krishnakumar V., Thampan P.K., Achuthan Nair M., The Coconut Palm (Cocos nucifera L.) - Research and Development Perspectives, Springer Nature Singapore, (2019).

9. Suman S., Gautam S., Energy Sources, Part A: Recovery, Utilization, and Environmental Effects, Vol. 39(8), pp. 761-767, (2017).

10. Anuar M.F., Fen Y.W., Mohd Zaid M.H., Matori, K. A., Mohamed Khaidir R. E., Results in Physics, Vol. 11, pp. 1-4, (2018).

11. Robinson A.L., Junker H., Baxter L.L., Energy Fuels, Vol. 16, pp. 343-355, (2002).

12. Bonneau X., Haryanto I., Karsiwan T., Experimental Agriculture, Vol. 46 (3), pp. 401-414, (2010).

13. Glarborg P., Computer Aided Chemical Engineering, Vol. 45, pp. 603-645, (2019).

14. Ren X., Rokni E., Liu Y., Levendis Y.A., Journal of Energy Engineering, Vol. 144(4), 04018045, (2018).

15. Billen P., Van Caneghem J., Vandecasteele C., Waste and Biomass Valorization, Vol. 5, pp. 879-892, (2014).

16. Anicic B., Agglomeration Mechanisms during Fluidized Bed Combustion of Biomass. Kgs. Lyngby: Technical University of Denmark (DTU), (2018).

17. Defoort F., Dupont C., Durruty J., Guillaudeau J., Bedel L., Ravel S., Campargue M., Labalette F., Da Silva Perez D., Energy Fuels, Vol. 29, pp. 7242-7253, (2015).

18. Scandrett L.A., Clift R., Journal of the Institute of Energy, Vol. 57(433), pp. 391-397, (1984).

19. Rowe J.J., Morey G.W., Zen C.S., The Quinary Reciprocal Salt System Na, K, Mg, Ca/Cl, $\mathrm{SO}_{4}-\mathrm{A}$ Review of the Literature with New Data, Geological survey professional paper 741, US Govt. Print. Off., (1972). 